\title{
Functional evaluation of marine micro-algae Amphidinium carterae extract
}

\author{
Hae-Mi Kim ${ }^{1}$, Hyeonhwa $\mathrm{Oh}^{2}$, Jong Hoon Jeong ${ }^{3}$, Sang-Cheon Lee ${ }^{4}$, \\ Hye-Jung Moon ${ }^{4}$, Yong-Seob Jeong ${ }^{2 *}$ \\ ${ }^{1}$ Research Center for Industrial Development of BioFood Materials, Chonbuk National University, Jeonju 54896, Korea \\ ${ }^{2}$ Department of Food Science and Technology, Chonbuk National University, Jeonju 54896, Korea \\ ${ }^{3}$ Institute of Jinan Red Ginseng, Jinan 55442, Korea \\ ${ }^{4}$ Imsil research Institute of Cheese Science and Food, Imsil 55918, Korea
}

\section{해양 미세조류 Amphidinium carterae 추출물의 기능성 평가}

\author{
김해미 ${ }^{1} \cdot$ 오현화 $^{2} \cdot$ 정종훈 $^{3} \cdot$ 이상천 $^{4} \cdot$ 문혜정 $^{4} \cdot$ 정용섭 $^{2 *}$ \\ ${ }^{1}$ 전북대학교 바이오식품소재개발 및 연구센터, ${ }^{2}$ 전북대학교 식품공학과, ${ }^{3}$ 진안홍삼연구소, \\ ${ }^{4}($ 재 $)$ 임실치즈 \& 식품연구소
}

\begin{abstract}
In this study, the antimicrobial, antioxidant activities and a-glucosidase inhibitory activities of Amphidinium carterae ethanol extract (AE) was evaluated for using as a functional food ingredient. Chlorella ethanol extract (CE) was used to the comparison as a control. Anticancer activities of the $\mathrm{AE}$ and $\mathrm{CE}$ were analyzed by HepG2 and HT-29 human cancer cell. The AE showed antimicrobial activities for all tested bacterial strains. Whereas, CE showed antimicrobial activities for several tested bacterial strains only. The CE showed higher total phenolics contents, DPPH and ABTS radical-scavenging activities $(47.36 \mathrm{mg} / \mathrm{g}, 22.42 \%$ and $28.58 \%$, respectively) than those of AE $(8.88 \mathrm{mg} / \mathrm{g}, 20.16 \%$ and $17.69 \%$, respectively). AE showed anti-diabetic effect on a-glucosidase inhibitory activity with dose-dependantly manner. The cell viability of $\mathrm{AE}(125 \mu \mathrm{g} / \mathrm{mL})$ on HepG2 and HT-29 human cancer cells were $38.12 \%$ and $11.27 \%$, respectively. It was demonstrated that ethanol was efficient solvent for extracting functional components from $A$. carterae. These results indicated that $\mathrm{AE}$ can be described as a good candidate for using as a functional food ingredient.
\end{abstract}

Key words : Amphidinium carterae, chlorella, antibacterial activity, antidiabetic activity, anticancer activity.

\section{서 론}

미세조류는 광합성을 하는 수중 단세포 생물로 일반적으 로 식물성 플랑크톤이라고 불린다. 최근 국내외 연구에 의 해 미세조류에는 당질, 지질, 색소, 비타민, 스테로이드와 기타 의약성분 등과 같은 다양한 생리활성물질들이 함유되

*Corresponding author. E-mail : ysjeong@jbnu.ac.kr Phone : 82-63-270-2571, Fax : 82-63-270-257

Received 3 July 2017; Revised 22 August 2017; Accepted 22 August 2017.

Copyright (c) The Korean Society of Food Preservation. All rights reserved.
어 있음이 밝혀졌다(1-3). 해양 미세조류 중 녹조류 (cyanobacteria)에 속하는 클로렐라는 다량의 엽록소, 필수 아미노산, 비타민, 미네랄, 핵산과 불포화지방산이 함유되 어있어 다양한 생리활성 효과가 있는 것으로 알려져 있다 (4).

한편, 와편모조류(Dinoflagellate)에 속하는 Amphidinium carterae는 광합성에 의해 쉽게 증식되며, 지질을 다량 함유 한 단세포 미세조류이다(5). 안전성측면에서 해양에 적조 현상으로 인한 어패류의 폐사와 관련해 Amphidinium spp. 의 독성이 연구되었고, Amphidinium operculatum 종이 생산 하는 polyketide(PK)류는 세포독성이 큰 것으로 알려졌다 (6). 하지만, Murray 등(6)은 Amphidinium spp.의 유전학적 
다양성(diversity)에 대한 보고에서 Amphidinium spp.와 $A$ carterae의 유전학적 서열차이가 커서 생산하는 $\mathrm{PK}$ 류가 다 르다고 하였다. 또한, Kellmann 등(7)에 의하면 $A$ carterae 은 신경성 패독(brevetoxin), 마비성 패 독(saxitoxin) 등의 조류독소(phycotoxin)을 합성하는 유전자를 보유하고 있지 않다고 하였다. A carterae는 Candida sp.와 Aspergillus niger의 증식을 억제하는 항진균 활성물질로 각각 amphidinol(8-10)과 carteraol $\mathrm{E}(11)$ 등을 생성하는 것으로 알려졌다. 따라서, $A$ carterae는 기능성 물질을 함유한 미세 조류로 그 이용가치에 대해 관심이 증대하고 있다.

미세조류의 기능성에 대한 연구의 결과로 클로렐라는 면역력 증진(12)과 항산화(13)에 도움되는 기능성 식품원 료로 등재되어 있고(14), 클로렐라 세포를 건조 분말화한 원말을 정제 또는 과립으로 가공한 것과 열수 추출물이 건강식품으로 이용되고 있다. $A$ carterae의 경우 클로렐라 와 비슷한 수준의 당질, 미네랄과 섬유질 등을 함유하고 있고, 특히 지질의 함량이 높은 것으로 보고되어(5) 지용성 기능성 물질에 대한 관심이 증대하고 있다. 최근에는 $A$ carterae 배양물의 메탄올 추출물 및 용매분획물에서 면역 활성과 항암활성이 우수한 것으로 보고되었다(5). 그러나, $A$ carterae의 에탄올추출물에 대한 항산화, 항균활성과 항 당뇨효과 등의 기능성 평가(in vitro)에 대한 연구는 미비한 실정이다.

본 연구에서는 건강기능식품의 소재로서 해양 미세조류 인 $A$ carterae의 이용 가능성을 클로렐라와 비교하여 확인 하고자 하였다. 이를 위해 $A$ carterae와 클로렐라 에탄올 추출물을 동결건조하여 분말화하여, 항산화, 항균활성과 항당뇨 효과를 측정하였고, 그리고 암세포주를 이용한 항 암활성 평가에 대해 농도의존성을 평가하였다. A carterae 의 기능성 평가결과를 토대로 건강기능성 식품으로서 $A$ carterae 에탄올 추출물의 가능성을 위한 기초 자료로 활용 하고자 하였다.

\section{재료 및 방법}

\section{실험재료 및 기기}

본 실험에서 사용된 $A$ carterae는 아쿠아진텍(Busan, Korea)으로부터 분양받아 동결 건조하여 분석시료로 하였 다. 실험 비교군인 클로렐라 분말은 (주대상(Gunsan, Korea) 의 제품을 구입하여, $-20{ }^{\circ} \mathrm{C}$ 이하의 암소에 보관하면서 추출 용 시료로 사용하였다. 추출물은 dimethyl sulfoxide (DMSO; Daejung chemical, Gwangju, Korea)에 녹여 사용하였다. 항균활성측정을 위한 미생물은 Escherichia coli 3종, Micrococcus luteous, Staphylococcus aureus, Listeria monocytogenes, Bacillus subtilis, B. licheniformis, B. cereus 4종과 Pseudomonas aeruginosa를 한국농업미생물자원 센
터(Korean Agricultural Culture Collection, KACC, Wanju, Korea)에서 분양받았으며, E. coli KCTC1039와 Klebsiella pneumoniae KCTC 2246를 생물자원센터(Korean Collection for Type Cultures, KCTC, Jeongup, Korea)에서 분양받아 사용하였다. 항암세포 활성 평가를 위한 세포주는 HepG2 (간암세포)와 HT-29(대장암세포)를 한국세포주은행(Korean Cell Line Bank, KCLB, Seoul, Korea)에서 분양받아 사용하 였다.

DPPH(2,2-Diphenyl-1-picrylhydrazyl), ABTS(2,2-azinobis-3-ethylenebenzothiozoline-6-sulfonic acid), ascorbic acid, pyrogallol, gallic acid, Folin-Ciocalteau reagent, a-glucosidase, 4-PNP-glycoside(p-NPG; p-Nitrophenyl a-D-glucopyranoside) 와 sodium carbonate등은 Sigma-Aldrich사(St. Louis, MO, USA), nutrient broth(NB)와 nutrient agar(NA) 등은 Difco사 (Difco, MD, USA)에서 구입하였고, 그리고 그 밖의 시약들 은 analytical 및 HPLC grade를 사용하였다. 세포활성평가를 위한 Dulbecco's modified Eagle's medium(DMEM), penicillin-streptomycin, Fetal Bovine Serum(FBS)와 Phosphate Buffer Saline(PBS)는 Gibco/BRL사(Burlington, ON, Canada) 제품을 구입하였고, Cell Counting Kit-8(CCK-8)은 CCK-8 (Dojindo, Kumamoto, Japan)을 사용하였다.

항온수조(TW-PC-1, Universal Scientific Industrial Co., Ltd., Shanghai, China), 회전증발 농축기(RV 10 basic, IKA, Staufen, Germany)과 동결건조기(Supermodulyo 220, Thermo Electron Co., Waltham, MA, USA)는 추출과 농축을 위하여 사용되었다.

\section{에탄올 추출물의 제조}

에탄올 추출은 $A$ carterae 및 클로렐라 분말에 10 배의 95\% 에탄올을 가한 후, 환류냉각기를 부착시킨 항온수조를 이용하여 1 시간동안 $70^{\circ} \mathrm{C}$ 에서 가열추출 하였으며, 이 과정 을 3회 반복하였다. 각 추출물은 여과지 Whatman No. 2(Whatman Co., Maidstone, England)로 여과한 다음 rotatory vacuum evaporator로 감압농축한 후 동결건조하여 분말로 제조하였다. 이를 $-70^{\circ} \mathrm{C}$ 이하의 암소에 보관하면서 DMSO 에 녹여 시료를 제조하였으며 일정농도로 희석하여 항산 화, 항균활성, 항당뇨 활성과 항암활성 측정을 위해 사용하 였다. 각각의 추출물 시료는 chlorella ethanol extract(CE), $A$ carterae ethanol extract(AE)로 명명하였다.

\section{총 페놀 함량}

Anesini(15)의 방법을 이용하여 미세조류 에탄올 추출물 에 대한 총 페놀 함량(total phenolics content, TPC)을 측정하 였다. 시료 $1 \mathrm{~mL}$ 에 $10 \%$ Folin-ciocalteu's phenol reagent $5 \mathrm{~mL}$ 를 가하여 실온에서 3 분간 반응시킨 후에 $7.5 \%$ $\mathrm{Na}_{2} \mathrm{CO}_{3}$ 용액 $4 \mathrm{~mL}$ 를 첨가하여 실온암소에서 2 시간동안 반응시켰다. 이 반응액을 분광광도계(UV-1650PC, Shimadzu 
$\mathrm{Co}$, Kyoto, Japan)를 이용하여 $765 \mathrm{~nm}$ 에서 흡광도를 측정하 였다. Gallic acid로 작성한 표준 검량곡선을 이용하여 시료 의 흡광도로부터 총 페놀 함량 $(\mathrm{mg} / \mathrm{g})$ 을 구하였다.

\section{항산화 활성 측정}

Kano 등(16)의 방법을 일부 변형하여 미세조류 에탄올 추출물에 대한 DPPH 라디컬 소거능을 측정하였다. 시료 $100 \mu \mathrm{L}$ 에 $100 \mu \mathrm{M} \mathrm{DPPH}$ 용액 $2 \mathrm{~mL}$ 를 첨가하여 암소에서 20 분간 반응시킨 후에 $515 \mathrm{~nm}$ 에서 흡광도를 측정하였으며 비교구로는 ascorbic acid를 사용하였다. DPPH radical 소거 능을 아래의 식으로 계산하였다.

DPPH radical-scavenging activity $(\%)=\left(\frac{\text { Absorbance }_{\text {control }}-\text { Absorbance }_{\text {sample }}}{\text { Absorbance }_{\text {control }}}\right) \times 100$

$\mathrm{Li}$ 등(17)의 방법을 이용하여 미세조류 에탄올 추출물에 대한 ABTS radical 소거능을 측정하였다. 시료 $30 \mu \mathrm{L}$ 에 $\mathrm{ABTS}$ radical 용액 $3 \mathrm{~mL}$ 를 첨가하여 암소에서 6 분간 반응 시킨 후에 $734 \mathrm{~nm}$ 에서 흡광도를 측정하였으며, 비교구로는 ascorbic acid를 사용하였다. ABTS radical 소거능을 아래의 식으로 계산하였다.

ABTS radical-scavenging activity $(\%)=\left(\frac{\text { Absorbance }_{\text {control }}-\text { Absorbance }_{\text {sample }}}{\text { Absorbance }_{\text {control }}}\right) \times 100$

\section{항균활성}

미세조류 에탄올 추출물에 대한 항균활성은 paper disc 확산법으로 비교분석하였다. 각각의 추출물 시료를 DMSO 를 이용하여 $100 \mathrm{mg} / \mathrm{mL}$ 농도로 stock solution을 조제한 후 일정한 농도범위로 희석하였다. 본 실험에 사용된 세균 은 $\mathrm{NB}$ 에 접종하여 $37^{\circ} \mathrm{C}$ 와 $200 \mathrm{rpm}$ 에서 18 시간 진탕 배양시 켜 활성 시킨 후 멸균된 면봉을 사용하여 NA에 도말하였다. 각 균이 도말된 NA 표면에 $6 \mathrm{~mm}$ paper disc(ADVANTEC, Tokyo, Japan)을 올리고, 그 위에 시료를 $20 \mu \mathrm{L}$ 점적하여 $37^{\circ} \mathrm{C}$ 에서 18 시간동안 정치 배양하였다. 이후 paper disc 주 위로 형성된 clear zone $(\mathrm{mm})$ 을 측정하여 항균력을 확인하 였고, 항균활성이 확인되는 최소저해농도(minimum inhibitory concentration, MIC)를 측정하기 위해 추출물의 농도를 조정 하여 점적한 후 clear zone의 생성여부을 확인하였다. Clear zone의 생성여부에 따라 최소저해농도를 결정하였다.

\section{항당뇨 효과}

미세조류 에탄올 추출물의 항당뇨 효과는 a-glucosidase inhibition(AGI) 활성을 이용하였고, Lim 등(18)의 방법을 실험조건에 맞게 변형하여 사용하였다. 추출물 시료는 각 각 $10 \mathrm{mg} / \mathrm{mL}$ 의 농도로 $\mathrm{DMSO}$ 에 용해하여 단계적으로 $\mathrm{ddH}_{2} \mathrm{O}$ 로 희석 $(0.025,0.05,0.1,0.25,0.5$ 와 $1 \mathrm{mg} / \mathrm{mL})$ 하여
사용하였다. 준비된 시료 $100 \mu \mathrm{L}$ 에 $0.2 \mathrm{mM}$ 4-NPG 200 $\mu \mathrm{L}$ 를 가하여 $37^{\circ} \mathrm{C}$ 에서 5 분간 평형상태를 유지한 후, 0.5 $\mathrm{U} / \mathrm{mL}$ 로 조제된 a-glucosidase $200 \mu \mathrm{L}$ 를 첨가하여 $37^{\circ} \mathrm{C}$ 에서 30 분간 반응하였다. 30 분 경과 후 $0.25 \mathrm{M} \mathrm{Na}_{2} \mathrm{CO}_{3} 500 \mu \mathrm{L}$ 를 첨가하여 반응을 종료시키고 $405 \mathrm{~nm}$ 에서 흡광도를 측정하 였다. 대조구(control)는 시료(sample) 대신 증류수를 첨가 하여 반응시켰다. 양성대조구로는 acarbose $(100 \mu \mathrm{g})$ 를 시료 대신 첨가해서 저해활성을 비교하였다. AGI의 활성은 아래 의 식으로 계산하였다.

$$
\text { AGI activity }(\%)=\left(\frac{\text { Absorbance }_{\text {control }}-\text { Absorbance }_{\text {sample }}}{\text { Absorbance }_{\text {control }}}\right) \times 100
$$

\section{암세포 생장억제 평가}

미세조류 에탄올 추출물의 암세포 생장억제는 $\mathrm{HepG} 2$ (간암 세포)와 HT-29(대장암 세포) 세포주의 세포 생존율을 측정하여 평가하였다. DMEM 배지에 penicillin $(100 \mathrm{U} / \mathrm{mL})$, streptomycin $(100 \mu \mathrm{g} / \mathrm{mL})$ 그리고 FBS를 $10 \%$ 로 첨가하여 조제하고, 세포 현탁과 배양배지도 사용하였다. 세포 현탁 액은 $\mathrm{DMEM}$ 배지를 이용하여 $5 \times 10^{4} \mathrm{cells} / \mathrm{mL}$ 의 농도로 조 절한 후 96 well plate의 각 well에 $100 \mu \mathrm{L}$ 씩 분주한 다음, $37^{\circ} \mathrm{C}$ 로 설정된 $5 \% \mathrm{CO}_{2}$ 배양기에서 24시간 배양하였다. 24 시간 후 추출물 시료농도가 $1 \mathrm{mg} / \mathrm{mL}$ 가 되도록 DMEM 배지를 사용하여 제조한 후, 이를 단계적으로 희석( 31.25 , 62.5 와 $125 \mu \mathrm{g} / \mathrm{mL}$ )하여 각각 $100 \mu \mathrm{L}$ 씩 첨가하고 $37^{\circ} \mathrm{C}$ 로 설정된 $5 \% \mathrm{CO}_{2}$ 배양기에서 48 시간 배양하였다. 배양 후 기존배지를 제거한 다음 PBS $100 \mu \mathrm{L}, \mathrm{CCK}-8$ solution 10 $\mu \mathrm{L}$ 씩을 각각 첨가한 후, $37^{\circ} \mathrm{C}$ 암소에서 2 시간 반응시켰다. 이어서 $0.1 \mathrm{~N} \mathrm{HCl}$ 을 $10 \mu \mathrm{L}$ 첨가하여 반응을 정지시킨 다음 $450 \mathrm{~nm}$ 에서 흡광도를 측정하였다. 암세포 생장억제능은 흡광도 측정결과를 아래의 식에 대입하여 세포 생존율로써 비교하였다. Blank는 시료액 대신 PBS를 사용하였고, control은 DMSO의 세포 생장 저해활성 고려하고자 시료액 대신 농도별 $\mathrm{DMSO}$ 를 첨가하여 측정하였다.

$$
\text { Cell viability }(\%)=\left(\frac{\text { Absorbance }_{\text {blank }} \text {-Absorbance }}{\text { sample }_{\text {e }}}\right) \times 100
$$

\section{통계처리}

각 실험에서 얻은 결과는 SPSS package program(Ver. $12.0 \mathrm{~K}, \mathrm{SPSS} \mathrm{Inc}$, Chicago, IL, USA)을 사용하여 평균과 표준편차로 나타내었다. 각 시료간의 유의성은 $\mathrm{p}<0.05$ 수준 에서 one way ANOVA로 분산분석한 후에 Duncan's multiple range test로 비교하였다.

\section{결과 및 고찰}

\section{총 페놀성 화합물 함량 및 항산화 활성}

미세조류 에탄올 추출물의 총 페놀성 화합물의 함량과 
항산화활성 측정결과는 Table 1 과 같다. $\mathrm{CE}$ 와 $\mathrm{AE}$ 의 $\mathrm{TPC}$ 는 각각 $47.39 \mathrm{mg} / \mathrm{g}$ 와 $8.88 \mathrm{mg} / \mathrm{g}$ 로 $\mathrm{CE}$ 의 총 페놀성 화합물의 함량이 $\mathrm{AE}$ 보다 5.33배 높았다. 클로렐라와 $A$ carterae 에탄 추출물의 DPPH 라디칼 소거활성의 경우, 추출물의 첨가량 이 $1-6 \mathrm{mg} / \mathrm{mL}$ 까지 증가함에 따라 농도 의존적으로 활성이 증가하였으나 $\mathrm{CE}$ 와 $\mathrm{AE}$ 의 최고 활성이 각각 $22.42 \%$ 와 $20.16 \%$ 이었고 다중검정의 결과 다른 그룹으로 분류되었다. $\mathrm{ABTS}$ 라디칼 소거능의 경우 $\mathrm{CE}$ 와 $\mathrm{AE}$ 의 최고활성이 각각 $28.58 \%$ 과 $17.69 \%$ 이었고 농도 의존적으로 증가하였다. Lee 와 Hong(13)에 의하면 클로렐라의 지용성 엽록소가 열수 추출보다 $50 \%$ 에탄올에 용출이 유리하다고 하였고, Kim 등(19)은 지용성용매 추출물에서 항산화활성이 우수하다 고 하였다. Kumar(20)는 클로렐라의 색소성분인 클로로필 린(chlorophyllin)이 활성 산소종을 제거하는 능력이 있다고 보고하였으므로, 클로렐라 에탄올 추출물의 항산화능은 클 로로필린 같은 색소성분과 페놀성 화합물에 기인된다고 판단되었다. 한편, $A$ carterae은 에탄올 추출물의 페놀성 화합물 양은 상대적으로 적었으나 항산화능을 보이는 것으 로 나타났다. $A$ carterae가 $6 \%$ 의 지질을 함유하고, $40 \%$ 이 상의 무기질을 함유하고 있으며(5), zeaxanthin 같은 carotenoid 합성이 가능하다 하였다(21). 따라서, $\mathrm{AE}$ 의 항산 화성분은 페놀성 화합물 이외에 지용성 색소나 무기질의 영향으로 추정된다(26).

\section{항균 활성}

그람음성세균 6 종과 그람양성세균 10 종이 도말된 배지 에 추출물을 일정농도 $(1-10 \mathrm{mg} / \mathrm{mL})$ 로 분주하고 성장억제 능을 측정하여 미세조류 에탄올 추출물의 항균활성을 확인 하였다. Disc 주변으로 clear zone의 생성농도를 기록해 최 소저해농도(MIC)로 하였고, $10 \mathrm{mg} / \mathrm{mL}$ 의 농도로 희석된 추출물의 항균활성 결과는 Table 2 와 같다. M. luteous, $S$. aureus, K pnumoniae는 항생제에 대한 내성을 가지는 균,
E. coli는 오염지표균, L. monocytogenes와 B. cereus는 식중 독 유발세균으로, 그리고 기타 Bacillus sp.은 내열성 및 내생 포자를 생성하는 균으로 분류된다. 본 연구에 사용된 16 종 의 세균류는 면역이 저하된 환자나 균이 오염된 식품의 섭취 시 인체에 유해하며, 식품에 오염되면 품질저하를 일 으킬 수 있어 제어가 필요한 균주이다. 따라서, 이들 세균에 대한 $\mathrm{CE}$ 의 항균활성은 E. coli 3종과 S. aureus, B. subtilis, B. licheniformis에 대해 확인되었으나, $\mathrm{AE}$ 의 항균활성은 B. licheniformis를 제외한 모든 실험균에서 $\mathrm{CE}$ 의 활성보다 높게 나타났다.

$A$ carterae의 항진균 물질은 amphidinol류와 carteraol E 로 알려졌는데, amphidinol은 메탄올 추출물의 부탄올분획 에서 분리되어 현재까지 18 개의 구조가 확인되었다(9). carteraol E는 메탄올 추출물의 에틸아세테이트분획에서 분 리된 지용성 물질이라고 보고되었다(11). A carterae 에탄 올 추출물에서 항균활성에 대한 연구는 미비한 상태이므로 항균물질에 대한 지속적인 연구가 필요하다. Pagliara와 Caroppo(22)는 $A$ carterae의 어류의 유전독성연구에서 $\mathrm{A}$. carterae 세포파쇄물의 농도 $3.75 \mathrm{mg} / \mathrm{mL}$ 에서 $50 \%$ 의 저해활 성을 보였고 용혈활성은 미약했다고 보고하여 $A$ carterae 의 안전성을 제시하였다. 따라서, 천연 항균물질을 탐색하 는 연구에서 해양미세조류인 $A$ carterae 에탄올 추출물의 항균활성은 높은 기대가치가 있다고 판단된다.

\section{항당뇨 효과}

미세조류 에탄올 추출물의 항당뇨 효과(in vitro)를 분석 하기 위해 AGI 활성을 측정하였고, 그 결과를 Fig. 1에 나타 내었다. a-glucosidase의 활성은 $\mathrm{CE}$ 의 경우 검출 한계치가 $100 \mathrm{\mu g} / \mathrm{mL}$ 이었으며, 농도증가에 따라 효소의 활성이 촉진 되는 것으로 분석되었다. 반면에 $\mathrm{AE}$ 는 25-500 $\mu \mathrm{g} / \mathrm{mL}$ 에서 농도 의존적으로 효소억제활성이 증가하였으며, $500 \mu$ $\mathrm{g} / \mathrm{mL}$ 농도에서 AGI 활성은 $82.07 \%$ 으로 확인되었다. Lee와

Table 1. Comparison of antioxidant activity and total phenolic contents for $\mathrm{CE}$ and $\mathrm{AE}$

\begin{tabular}{|c|c|c|c|c|c|c|c|}
\hline \multirow{2}{*}{ Properties ${ }^{1)}$} & & \multirow{2}{*}{ Sample $^{2)}$} & \multicolumn{4}{|c|}{ Concentration $(\mathrm{mg} / \mathrm{mL})$} & \multirow{2}{*}{$0.1 \%$ Ascorbic acid) } \\
\hline & & & 1 & 2 & 4 & 6 & \\
\hline \multirow{4}{*}{ Antioxidant activity (\%) } & \multirow{2}{*}{ DPPH } & $\mathrm{CE}$ & $7.91 \pm 0.05^{4) \mathrm{d} 5) \mathrm{G} 6}$ & $11.35 \pm 0.50^{\mathrm{CE}}$ & $17.50 \pm 0.41^{\mathrm{bC}}$ & $22.42 \pm 0.18^{\mathrm{aA}}$ & \multirow{2}{*}{$59.8 \pm 0.30$} \\
\hline & & $\mathrm{AE}$ & $9.99 \pm 0.23^{\mathrm{dF}}$ & $13.29 \pm 0.09^{\mathrm{cD}}$ & $17.41 \pm 0.32^{\mathrm{bC}}$ & $20.16 \pm 0.09^{\mathrm{aB}}$ & \\
\hline & \multirow{2}{*}{ ABTS } & $\mathrm{CE}$ & $11.68 \pm 0.07^{\mathrm{dF}}$ & $15.90 \pm 0.00^{\mathrm{cD}}$ & $21.78 \pm 0.14^{\mathrm{bB}}$ & $28.58 \pm 0.21^{\mathrm{aA}}$ & \multirow{2}{*}{$44.88 \pm 0.21$} \\
\hline & & $\mathrm{AE}$ & $9.74 \pm 0.14^{\mathrm{dG}}$ & $12.03 \pm 0.43^{\mathrm{cF}}$ & $14.40 \pm 0.36^{6 \mathrm{E}}$ & $17.69 \pm 0.50^{\mathrm{aC}}$ & \\
\hline \multirow{2}{*}{ TPC (mg/g) } & & $\mathrm{CE}$ & & & $47.39 \pm 0.39$ & & \\
\hline & & $\mathrm{AE}$ & & & $8.88 \pm 0.07$ & & \\
\hline
\end{tabular}

\footnotetext{
${ }^{1)} \mathrm{DPPH}$, DPPH radical scavenging ability; ABTS, ABTS radical scavenging ability; TPC, total phenolic contents.

${ }^{2)} \mathrm{CE}$, chlorella ethanol extract; $\mathrm{AE}, A$ carterae ethanol extract.

${ }^{3} 0.1 \%$ ascorbic acid, positive control for antioxidant activity.

${ }^{4)}$ Values are mean $\pm \mathrm{SD}(\mathrm{n}=3)$.

${ }^{5}$ Different small letters in the same row are significantly different by Duncan's multiple test $(\mathrm{p}<0.05)$.

${ }^{6}$ Different capital letters in the same activity are significantly different by Duncan's multiple test $(\mathrm{p}<0.05)$.
} 
Table 2. Antimicrobial activities of the micro-algae ethanol extracts against bacteria

\begin{tabular}{|c|c|c|c|c|}
\hline \multirow{2}{*}{ Strains } & \multicolumn{2}{|c|}{ Inhibition zone (mm) } & \multicolumn{2}{|c|}{$\mathrm{MIC}^{1)}(\mathrm{mg} / \mathrm{mL})$} \\
\hline & $\mathrm{CE}^{2)}$ & $\mathrm{AE}$ & $\mathrm{CE}$ & $\mathrm{AE}$ \\
\hline \multicolumn{5}{|l|}{ Gram negative } \\
\hline E. coli $\mathrm{KACC} 10115$ & $\mathrm{ND}^{3)}$ & $9.99 \pm 0.36^{4) d 5}$ & - & 5 \\
\hline E. coli KACC 13964 & $7.76 \pm 0.50^{\mathrm{d}}$ & $9.33 \pm 0.70^{\text {ef }}$ & 10 & 5 \\
\hline E. coli KACC 6017 & $7.17 \pm 0.03^{\mathrm{de}}$ & $9.84 \pm 0.02^{\mathrm{d}}$ & 10 & 10 \\
\hline E. coli KCTC 1039 & $6.81 \pm 0.04^{\mathrm{e}}$ & $9.78 \pm 0.06^{\mathrm{de}}$ & 10 & 10 \\
\hline P. aeruginasa KACC 10259 & $\mathrm{ND}$ & $9.70 \pm 0.58^{\text {de }}$ & - & 5 \\
\hline K. pnumoniae КCTC 2246 & $\mathrm{ND}$ & $10.74 \pm 0.25^{\mathrm{ab}}$ & - & 5 \\
\hline \multicolumn{5}{|l|}{ Gram positive } \\
\hline M luteous KACC 11307 & $\mathrm{ND}$ & $10.49 \pm 0.29^{\mathrm{bc}}$ & - & 5 \\
\hline S. aureus KACC 1927 & $8.53 \pm 0.38^{c}$ & $9.32 \pm 0.13^{\mathrm{ef}}$ & 10 & 5 \\
\hline L. monocytogenes KACC 10764 & $\mathrm{ND}$ & $10.91 \pm 0.08^{\mathrm{ab}}$ & - & 10 \\
\hline B. subtilis KACC 10854 & $10.08 \pm 0.10^{b}$ & $11.14 \pm 0.04^{\mathrm{a}}$ & 10 & 5 \\
\hline B. licheniformis KACC 10496 & $11.34 \pm 0.52^{\mathrm{a}}$ & $9.93 \pm 0.16^{\mathrm{d}}$ & 5 & 5 \\
\hline B. cereus KACC 10097 & $\mathrm{ND}$ & $10.20 \pm 0.13^{\mathrm{cd}}$ & - & 5 \\
\hline B. cereus KACC 13066 & $\mathrm{ND}$ & $9.91 \pm 0.19^{\mathrm{d}}$ & - & 5 \\
\hline B. cereus KACC 13064 & $\mathrm{ND}$ & $9.28 \pm 0.16^{\mathrm{f}}$ & - & 5 \\
\hline B. cereus KACC 12682 & $\mathrm{ND}$ & $10.50 \pm 0.37^{\mathrm{bc}}$ & - & 5 \\
\hline B. cereus KACC 12672 & $\mathrm{ND}$ & $9.00 \pm 0.02^{\mathrm{f}}$ & - & 5 \\
\hline
\end{tabular}

${ }^{1)} \mathrm{MIC}$, minimum inhibitory concentration.

${ }^{2)} \mathrm{CE}$, chlorella ethanol extract; $\mathrm{AE}, A$ carterae ethanol extract.

${ }^{3} \mathrm{ND}$, not detected.

${ }^{4)}$ Values are mean $\pm \mathrm{SD}(\mathrm{n}=3)$.

${ }^{5}$ Different small letters in the same column are significantly different by Duncan's multiple test $(\mathrm{p}<0.05)$.

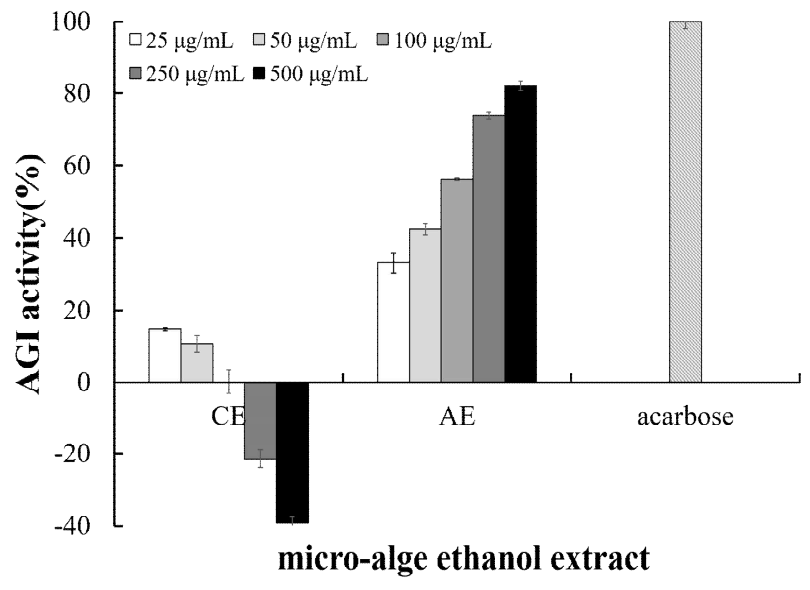

Fig. 1. a-Glucosidase inhibition activity of micro-algae ethanol extract.

p-NPG were treated with the extracts (CE, chlorella ethanol extract; AE, $A$ carterae ethanol extract) at the indicated concentrations as $25,50,100,250$ and $500 \mathrm{\mu g} / \mathrm{mL}$, respectively. Acarbose $(100 \mu \mathrm{g} / \mathrm{mL})$, positive control for AGI activity $(\%)$.

Values represent the mean $\pm \mathrm{SD}(\mathrm{n}=3)$.

$\operatorname{Jeon}(23)$ 의 연구에 따르면 감태와 패 같은 갈조류의 phlorotannins이라는 성분이 a-glucosidase를 억제한다고 하
였으며, 조류가 생산하는 fucoxanthin 등의 allenic catotenoid 류에 의한 항당뇨 효과가 보고(24)되었기 때문에, 미세조류 인 $A$ carterae의 a-glucosidase 억제활성 원인물질에 대한 연구가 필요하다고 생각된다.

\section{암세포 생장억제효과}

간암세포주인 HepG2와 대장암세포주인 HT-29에 대해 미세조류 추출물의 암세포에 대한 생장억제효과로서 세포 에 대한 생존율을 확인한 결과를 Fig. 2에 나타내었다. HepG2의 세포생존율 결과(Fig. 2A)에 의하면 추출물을 녹 이는데 사용된 $\mathrm{DMSO}$ 는 생장에 억제작용을 하지 않았으며, $\mathrm{CE}$ 의 경우 추출물 첨가농도의 범위 31.25 에서 $125 \mathrm{\mu g} / \mathrm{mL}$ 까 지 첨가량이 증가함에 따라 세포생장이 촉진되는 것으로 확인되었다. 반면, $\mathrm{AE}$ 의 경우 첨가농도 $62.5 \mu \mathrm{g} / \mathrm{mL}$ 에서 생존율이 $58 \%$ 로 감소하였고, $125 \mathrm{\mu g} / \mathrm{mL}$ 에서 $38 \%$ 로 유의 적으로 감소하여 간암세포(HepG2)의 생장이 억제됨을 보 였다.

HT-29의 세포 생존율 결과(Fig. 2B)에 의하면 추출물 125 $\mu \mathrm{g} / \mathrm{mL}$ 을 용해하는데 사용된 $\operatorname{DMSO}(0.625 \%)$ 의 농도에서 $20 \%$ 이내의 저해활성이 있었다. DMSO의 HT-29 세포에 
대한 저해활성에도 불구하고 $\mathrm{CE}$ 의 경우 $100 \%$ 이상의 생존 률이 확인됨에 따라 HepG2의 결과와 유사하게 세포성장이 촉진되는 것으로 판단되었다. 한편 $\mathrm{AE}$ 의 경우 추출물 첨가 량이 증가함에 따라 $125 \mu \mathrm{g} / \mathrm{mL}$ 농도에서 생존률이 $11.27 \%$ 로 확인됨에 따라 $75.41 \%$ 의 억제됨이 확인되었다.

다른 연구에 따르면 동물실험에서 클로렐라에 함유된 당단백질이 helper-T 세포를 강하게 활성화하여 암세포를 억제한다고 알려졌으나(25), 암세포에 직접 작용하는 클로 렐라 추출물의 억제효과는 나타나지 않았다. Samarakoon 등(5)에 의해 보고된, $A$ carterae 메탄올 추출물 용매분획에 서 HL-60(혈액암세포), B16F10(피부암세포), $\mathrm{A} 549$ (폐암세 포)의 증식억제능 효과와 유사하게 본 연구에서도 $A$ carterae 에탄올 추출물의 항암세포활성이 클로렐라 에탄 올 추출물보다 우수하였다.

이와 같은 결과를 종합해보면, $A$ carterae 에탄올 추출물 의 기능성 평가(in vitro)결과 항산화활성, 항당뇨효과와 암 세포 증식저해 활성이 농도의존성으로 증가하였다. 그리고
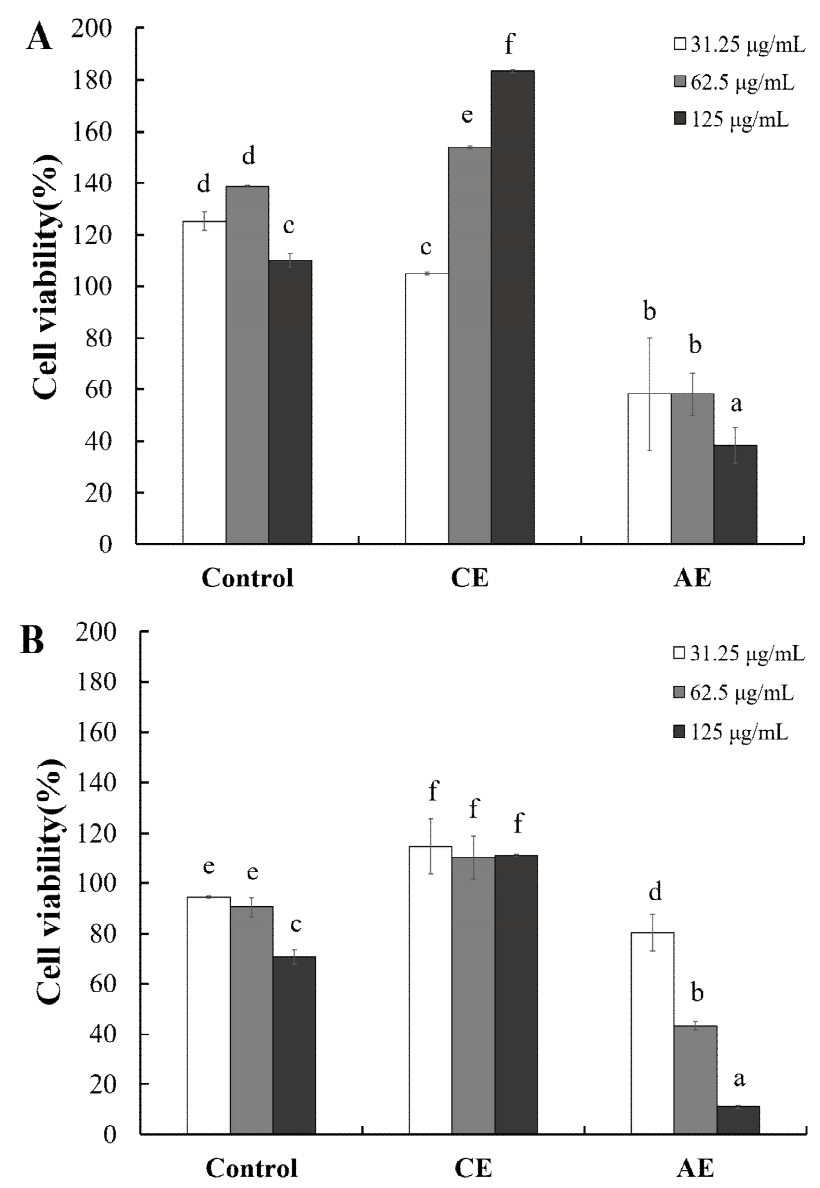

Fig. 2. Inhibitory effect of the growth of cancer cells against marine micro-algae chlor ella and $A$ carterae ethanol extract.

A, HepG2 cell line; B, HT-29 cell line. Cell were treated with the extracts (CE, chlorella ethanol extract; AE, $A$ carterae ethanol extract) at the indicated concentrations as 31.25 , 62.5 and $125 \mu \mathrm{g} / \mathrm{mL}$, respectively. Control, DMSO.

Values represent the mean $\pm \mathrm{SD}(\mathrm{n}=3)$. Means with different letters above a bar are significantly different at $\mathrm{p}<0.05$.
본 연구에 사용된 모든 세균류에 대한 항균활성이 확인되었 다. 따라서, $A$ carterae의 기능성 물질이 에탄올에 용출됨을 확인하였고, 페놀성 화합물 이외의 지용성 물질의 성분이 기능성을 보이는 것으로 추정된다. $A$ carterae 에탄올 추출 물의 기능성 물질 분리조건을 확립하는 지속적인 연구가 필요하다고 판단된다.

\section{요 약}

본 연구에서는 해양미세조류 $A$ carterae의 기능성 평가 를 위해 에탄올 추출을 하였고, 기존의 건강기능성식품인 클로렐라를 에탄올 추출하여 기능성을 비교하였다. 클로렐 라 에탄올 추출물(CE)과 $A$ carterae 에탄올 추출물 $(\mathrm{AE})$ 의 총페놀성 화합물은 각각 $47.39 \mathrm{mg} / \mathrm{g}$ 과 $8.88 \mathrm{mg} / \mathrm{g}$ 으로 $\mathrm{CE}$ 가 5.33 배 높았으나, DPPH 라디컬소거능은 $22.42 \%$ 와 $20.16 \%$ 로 비슷한 수준이었다. 반면에 $\mathrm{CE}$ 와 $\mathrm{AE}$ 의 $\mathrm{ABTS}$ 라디컬 소거능은 각각 $28.58 \%$ 와 $17.69 \%$ 로 $\mathrm{CE}$ 가 높아 $\mathrm{CE}$ 의 항산화 능은 페놀성 화합물의 효과로 판단된다. $\mathrm{AE}(10 \mathrm{mg} / \mathrm{mL})$ 의 항균활성은 그람음성균 6 종과 그람양성균 10 종에서 확인 하였다. 그리고 $\mathrm{CE}(10 \mathrm{mg} / \mathrm{mL})$ 의 항균활성은 그람음성균 3 종과 그람양성균 3종에서 확인되었다. a-glucosidase의 억 제활성은 $\mathrm{AE}(500 \mu \mathrm{gg} / \mathrm{mL})$ 에서 $82.07 \%$ 이었고, $\mathrm{CE}$ 는 효소활 성을 촉진하는 것으로 나타났다. 암세포 생장억제활성은 $125 \mu \mathrm{g} / \mathrm{mL}$ 농도의 $\mathrm{AE}$ 를 첨가했을 때, HepG2와 HT-29의 생존율이 각각 $38 \%$ 와 $11.27 \%$ 이었다. $31.25-125 \mathrm{\mu g} / \mathrm{mL}$ 의 농도범위에서 $\mathrm{CE}$ 첨가가 $\mathrm{HepG} 2$ 와 HT-29의 생장을 촉진하 는 것으로 확인되었다. 이와 같은 결과를 종합하면, $A$ carterae 에탄올 추출물은 페놀성 화합물 이외의 항산화 물질을 보유하고, 항균활성, 항당뇨효과와 암세포 억제활 성이 우수한 기능성 물질을 함유하고 있는 것으로 판단되어 기능성 소재로써의 활용가치가 높을 것으로 판단된다.

\section{감사의 글}

본 연구는 산업통상자원부와 한국산업기술진흥원이 지원하는 경제협력권산업 육성사업으로 수행된 연구결 과입니다(R0004370).

\section{References}

1. Oh HM, Choi AR, Mheen TI (2003) High-value Materials from Microalge. Kor J Microbiol Biotechnol, 31, 95-102

2. Kim SK, Back HC, Byun HG, Kang OJ, Kim JB (2001) Biochemical composition and antioxidantive activity of 
marine microalgae. J Korean Fish Soc, 34, 260-267

3. Batista AP, Gouveia L, Bandarra NM, Franco JM, Raymundo A (2013) Comparison of microalgal biomass profiles as novel functional ingredient for food products. Algal reaearch, 2, 164-173

4. Jelinek L, Prochazkova G, Quintelas C, Beldikova E, Branyik, T (2015) Chlorella vulgaris biomass enriched by biosorption of polyphenols. Algal Reserch, 10, 1-7

5. Samarakoon KW, Ko JY, Shah MMR, Lee JH, Kang MC, Nam WO, Lee JB, Jeon YJ (2013) In vitro studies of anti-inflammatory and anticancer activities of organic solvent extracts from cultured marine microalgae. Algae, 28, 111-119

6. Kellmann R, stuken A, Orr RJ, Svendsen HM, Jakobsen KS (2010) Biosynthesis and molecular genetics of polyketides in marine dinoflagellates. Mar Drugs, 8, 1011-1048

7. Murray SA, Garby T, Hoppenrath M, Neilan BA (2012) Genetic diversity, morphological uniformity and polyketide production in dinoflagellates (Amphidniium, Dinoflagellata). PLoS One, 7, 1-14

8. Meng YH, Van Wagoner RM, Misner I, Tomas C, Wright JLC (2010) Structure and biosynthesis of amphidinol 17, a hemolytic compound from Amphidinium carterae. J Nat Prod, 73, 409-415

9. Nuzzo G, Cutignano A, Sardo A, Fontana A (2014) Antifungal amphidinol 18 and its 7-sulfate derivative from the marine dinoflagellate Amphidinium carterae. J Nat Prod, 77, 1524-1527

10. Echigoya R, Rhodes L, Oshima Y, Satake M (2005) The structures of five new antifungal and hemolytic amphidinol analogs from Amphidinium carterae collected in New Zealand. Harmful Algae, 4, 383-389

11. Huang SJ, Kuo CM, Lin YC, Chen YM, Lu CK (2009) Carteraol E, a potent polyhydrxyl ichthyotoxin from the dinoflagellate Amphidinium carterae. Tetrahedron Lett, 50, 2512-2515

12. Guzman S, Gato A, Lamela M, Freire-Garabal M, Calleja JM (2003) Anti-inflammatory and immunomodulatory activities of polysaccharide from Chlorella stigmatophora and Phaeodactylum tricornutum. Phytother Res, 17, 665-670

13. Lee DH, Hong JH (2015) Antioxidant activities of chlorella extracts and physicochemical characteristics of spray-dried chlorella powders. Korean J Food Preserv, 22, 591-597
14. Son MK (2016) Current Status of Raw Material Function for Food Function. Ministry of Food and Drug Safety, Korea, p 1-115

15. Anesini C, Ferraro GE, Filip R (2008) Total polyphenol content and antioxidant capacity of commercially available tea (Camellia sinensis) in Argentina. J Agric Food Chem, 56, 9225-9229

16. Kano M, Takayanagi T, Harada K, Makino K, Ishikawa F (2005) Antioxidative activity of anthocyanins from purple sweet potato, Ipomoera batatas cultivar Ayamurasaki. Biosci Biotechnol Biochem, 69, 979-988

17. Li X (2012) Improved pyrogallol autoxidation method: a reliable and cheap superoxide-scavenging assay suitable for all antioxidants. J Agric Food Chem, 60, 6418-6424

18. Lim CS, Li CY, Kim YM, Lee WY, Rhee HI, (2005) The inhibitory effect of corus walteri extract against a -amylase. J Appl Biol Chem, 48, 103-108

19. Kim SK, Baek HC, Byun HG, Kang OJ, Kim JB (2001) Biochemical composition and antioxidative activity of marine microalgae. J Korean Fish Soc, 34, 260-267

20. Kumar SS, Devasagayam TPA, Bhushan B, Verma NC (2001) Scavenging of reactive oxygen species by chlorophyllin: an ESR study. Free Radic Res, 35, 563-574

21. Takaichi S (2011) Caroenoids in algae: distributions, biosynthesis and functions. Mar Drugs, 9, 1101-1118

22. Pagliara P, Caroppo C (2012) Toxicity assessment of Amphidinium carterae, Coolia cfr. monotis and Ostreopsis cfr. ovata (Dinophyta) isolated from the northern Ionian Sea (Mediterranean Sea). Toxicon, 60, 1203-1214

23. Lee SH, Jeon YJ (2013) Anti-diabetic effects of brown algae derived phlorotannins, marine polyphenols through diverse mechanisms. Fitoterapia, 86, 129-136

24. Miyashita K, Maeda H, Okada T, Abe M, Hosokawa M (2010) Anti-obesity and anti-diabetic effects of allenic carotenoid, fucoxanthin. Agro FOOD Industry Hi Tech, $21,24-27$

25. Noda K, Ohno N, Tanaka K, Kamiya N, Okuda M, Yadomae T, Nomoto K, Shoyama Y (1996) A water-soluble antitumor glycoprotein from Chlorella vulgaris. Planta Med, 62, 423-426

26. Shah MR, Samarakoon KW, An SJ, Jeon UJ, Lee JB (2016) Growth characteristeics of three benthic dinoflagellates in mass culture and their antioxidant protperties. J Fish Aquat Sci, 11, 268-277 